\title{
ANALYSIS OF PRODUCTION POTENTIAL AND COMPETITIVE POSITION OF SERBIA ON THE INTERNATIONAL WINE MARKET ${ }^{1}$
}

\author{
Jelena Petrović2 ${ }^{2}$ Bojan Krstić3 ${ }^{3}$ Tanja Stanišićc ${ }^{4}$
}

\begin{abstract}
Summary
The purpose of this research is analysis and forecasting of the most important trends on the international wine market, as well as identifying opportunities for wine export from Serbia. The aim of the research is to analyse the movement of the wine production and trade on the international market by applying the appropriate methodology. The paper is structured in the following segments: 1) examining the impact of number of vines and yields per vine on the acheved volume of grape production in the Republic of Serbia in the observed period; 2) examining the competitive position of the Republic of Serbia on the international wine market; and 3) analysis of the value and structure of foreign trade of wine between the Republic of Serbia and other countries. Comparative analysis, correlation analysis and regression analysis are used in the paper. The results of this paper indicate: 1) higher impact of yields per vine on the volume of grape production in relation to the impact of the number of vines on the volume of grape production; 2) increasing deficit of foreign trade of wine between Serbia and other world countries; and 3) that Serbia reduced coverage of import of wine by export of wine in the observed period.
\end{abstract}

Keywords: wine, production, market, foreign exchange.

JEL: $Q 1, F 1$.

1 Paper is a part of research within the project No. 179066 - Improving the competitiveness of the public and private sector by networking competences in the process of the European integrations of Serbia, financed by the Ministry of Education, Science and Technological Development of the Republic of Serbia.

2 Jelena Petrović, Ph.D., Assistant professor, University of Niš, Faculty of Mathematics and Science, Višegradska Street 33, 18000 Niš, Serbia, Phone: +381631132768, E-mail: jelenapetrovic619@yahoo.com

3 Bojan Krstić, Ph.D., Associate professor, University of Niš, Faculty of Economics, Trg Kralja Aleksandra 11, 18000 Niš, Serbia, E-mail: bojan.krstic@eknfak.ni.ac.rs

4 Tanja Stanišić, Ph.D., Assistant professor, University of Kragujevac, Faculty of Hotel Management and Tourism in Vrnjačka Banja, Vojvodanska Street nn., 36210 Vrnjačka Banja, Serbia, E-mail: tanja.stanisic@gmail.com

EP 2015 (62) 3 (813-829) 


\section{Introduction}

Favourable climatic conditions and geographic location of Serbia are its main comparative advantage in the production and placement of wine. Serbia is a continental country located in Southeastern Europe, in the central part of the Balkan Peninsula, between $41^{\circ} 53^{\prime}$ and $46^{\circ} 11^{\prime}$ of north geographic latitude and $18^{\circ} 49^{\prime}$ and $23^{\circ} 00^{\prime}$ of east geographic longitude. Because of the Pannonian Plain in the north, Serbia belongs to the region of Central Europe. Good geographic latitude contribute to adequate temperature conditions that are crucial to the amount of sugar that grapes contain, that is further important for the production of high quality wine. The climate of Serbia is moderately continental, with more or less expressed local characteristics and a gradual change between seasons. Serbia has a good regime of light, which is, in addition to temperature, a decisive factor for a sufficient amount of extract which is transformed into wine. The average volume of rainfall is partly satisfactory for grape production. Insufficient volume of rainfall during the vegetation can be overcome with sprinkler systems.

Given the very favourable climatic - geographical conditions, it is not surprising that viticulture has a long tradition in Serbia. According to numerous historical sources, viticulture and enology in Serbia have been developing more than a thousand years. Start of viticulture development is related to the formation of the Serbian state in the VIII and IX century and its significant development is linked to the reign of Nemanjić dynasty from the XI to the XIV century. Today, the viticulture and enology are widespread in Serbia and wine culture is a part of the tradition. Climate and soil in Serbia are favourable for vine growing, therefore it is grown in several regions with its' wine grooving sub-regions and areas (the most famous are Subotica, Bačka, South-Banat, Belgrade, Šumadija, Mlava, Niš, Knjaževac, Leskovac, Vranje, South and North Kosovo and Metohija, as well as subregions of Tri Morave and Negotinska Krajina) (Vlahović et al., 2012).

However, it comes to a reduction in the vineyards in the late XX and the early XXI century. According to data of the Statistical Office of the Republic of Serbia, the vineyards in Serbia are reduced from 70,634 hectares to about 22,150 hectares during the last decade. It is necessary to point out that there was as much as 100,000 hectares under the vineyards in Serbia in the eighties of the XX century (Statistical Office of the Republic of Serbia, 1998). Another trend, that characterized the first decade of the XXI century, is the formation of significant areas with contemporary assortment, as well as with varieties adapted to our circumstances. It is necessary to point out that the establishment of new wineries and wine cellars that are characterized by the quality of grapes planted and production of high quality wines. It is anticipated that if Serbia success to restore a few of denary thousand hectares of vineyards in the next seven to ten years, with continuity of state stimulation and with good development policy, the production and export of wine can significantly increase. However, the limit of the achievement of this goal is the fact that the costs of raising new vineyards are high. It takes averagely from $€ 12,000$ to $€ 15,000$ of investment per hectare, depending on what kind of equipment and infrastructure producer has (Vlahović et al., 2008). Due to limited financial and other resources, it is necessary a strategic approach and a serious analysis of all options, but, in particular, limitations of Serbia to promote and further develop viticulture and enology. 
The international wine market is subject of the changes. Globalization is not new to the world wine markets, but its influence has increased significantly. One indicator of that is the growth in the share of global production of wine that is exported (Anderson et al., 2001). The decisive potential in the global wine trade will, however, vary among the individual countries, also depending on the volume of production and the possibilities of its expansion (Kucerova, 2014). In the modern business world, which is characterized by a dynamic and continuous changes, the competitive ability of the company depends on the speed with which it can introduce new, superior products/services and innovate various business processes in relation to its rivals on the market (Krstić, Petrović, 2012). Wine producers should adapt the production, distribution and implement innovated strategies in line with future changes on the international wine market. It can be expected that Serbia's entry into the European Union will increase market opportunities for Serbian producers through potentially increasing sales of local wines. On the other hand, a larger market means more competition, and the only producers of quality wines and recognizable brands can expect increases of sales and profitability. Being competitive in export markets is, however, only a partial measure of an industry's overall performance; it also depends on its ability to defend its domestic market share (Fleming et al., 2014). Within the grape and wine sectors in many regions, there are fears of rising import competition and shrinking consumer demand (Wittwer, Rothfield, 2005). Wine producers in Serbia are necessary to increase the wine production with the simultaneous change of structure from the point of view of quality, and according to the market demands (Vlahović et al., 2011). They can achieve their business objectives in terms of target groups of buyers and consumers (Prdić et al., 2014).

Wine producers must recognize that the most effective way to compete on the global market is to trigger a systemic organization and produce consistently highquality product at a reasonable price (Fronkova, 2011). The concept of profitability has been widely debated in the international scientific economic community (Vita, Amico, 2013). According to Harward, Upto (1961) "profitability is the ability of a given investment to earn a return from its use" which applied to the profitability of agricultural holdings, regional and traditional foods have been conceptualised as a form of cultural and social capital, providing rural areas with social and economic benefits (Tregear et al., 2007; Arfini et al. 2011). One of the ways of improving wine production is mutual communication and cooperation between producers. This cooperation enable coordinated approach to research and development, a well-developed supply chain, sustainable alliances between growers, producers and support industries, significant public and private sector partnership and a unified marketing strategy (Fronkova, 2011). As consumers around the world become more educated, the wine industry may grow increasingly - like the best wine (Cox, Bridwell, 2007). Modern conditions, in addition to a number of limitations, offer great opportunities for improving production of individual wine producers. 


\section{Research methodology and hypotheses}

Alcoholic drinks are very important and special group of agricultural products in the overall development of the economy, and in particular, in the development of agriculture and rural areas (Đorović et al., 2012). In this paper, the scope and dynamics of production of wine in the world and in some countries which are leading wine producers in the world are analysed as an important market indicators. Special attention is devoted to the production of grapes and wine in Serbia, as well as to its competitive position in the international wine market. It is especially pointed out the characteristics of wine foreign trade of Serbia with other countries. The main goal of this research is to apply the appropriate methodology to estimate the volume of grape production in the Republic of Serbia, but also to analyse the movement of production and trade of wine on the domestic and international wine market. The specific objectives of the research are: a) examining the correlation between the volume of production, on the one hand, and the number of vines and yields per vine, on the other hand; b) analyzing the tendencies on the international wine market, as well as the competitive position of Serbia in it; c) determining the existence of a deficit or surplus of Serbian wine foreign trade with other countries of the world, starting from the relationship between the volume of import and export of wine; d) consideration of the coverage of wine import by wine export from 2004 to 2013; and 5) pointing to the nessesary measures and actions which should be taken in order to increase wine export from Serbia to the international market.

The basic starting hypothesis of the research are:

H1: There is a greater impact of yield per vine on the total volume of grape production, compared with the impact of the number of vines on the total volume of grape production in Serbia;

H2: The structure of the international wine market has changed in the observed period;

H3: Deficit of wine foreign trade of Serbia with the other countries in the world is increased;

H4: More intensive increase of wine import in relation to the increase of wine export is recorded in Serbia, or the coverage of wine import by wine export is reduced in the observed period.

In addition to national sources, international statistical publications of importance for the production and distribution of wine are used as information bases of this research.

According to the sources and characteristics of the data, but in order to test the basic hypothesis and research questions, the relevant following methods are applied in this paper: comparative analysis, correlation analysis and regression analysis.

\section{Determinants of grape production in the Republic of Serbia}

Grape production is widespread in the world, especially in Europe. Viticulture represents a highly intensive agricultural branch, which requires significant capital and labor investment 
per unit of output. Therefore, its development may affect the reduction of unemployment rate in rural areas.

Viticulture is a traditional agricultural branch in Serbia. Serbia has favorable natural conditions for the growing of this crop plant. Serbia was known as a wine-growing country in the Middle Ages. Newer period of development of viticulture production began in the sixties of the last century. Changes in demand on the domestic and international market have caused changes in the production of grapes. Plantation of vineyards with a different of high-yield varieties have been made. Modern machinery in processing, protection and grape harvest is emploed on new rased vineyards. Table 1 shows the results achieved in grape production in Serbia from 2004 to 2013.

There was a tendency of decreasing the number of vines at an average annual rate of $3.83 \%$ in the Republic of Serbia from 2004 to 2013. This caused that the total grape production was reduced by $24.50 \%$. The yield per vine was varied from 0.7 kilograms per vine (in 2005) to 1.5 kilograms per vine (in 2009).

Table 1. Vines, production and yield of grapes in the Republic of Serbia

\begin{tabular}{|c|c|c|c|}
\hline Year & $\begin{array}{c}\text { Number of vines } \\
\text { (in thousands) }\end{array}$ & $\begin{array}{c}\text { Total production } \\
\text { (in tonnes) }\end{array}$ & $\begin{array}{c}\text { Yield per unit } \\
\text { (in kilograms) }\end{array}$ \\
\hline 2004 & 347,000 & 424,511 & 1.3 \\
\hline 2005 & 337,000 & 240,643 & 0.7 \\
\hline 2006 & 322,000 & 359,454 & 1.1 \\
\hline 2007 & 309,000 & 353,343 & 1.1 \\
\hline 2008 & 300,000 & 372,967 & 1.2 \\
\hline 2009 & 291,000 & 431,306 & 1.5 \\
\hline 2010 & 292,000 & 330,070 & 1.2 \\
\hline 2011 & 273,614 & 324,919 & 1.0 \\
\hline 2012 & 267,356 & 263,419 & 1.3 \\
\hline 2013 & 244,087 & 320,491 & \\
\hline
\end{tabular}

Source: Statistical Office of the Republic of Serbia, Crop Production, available at: http://webrzs. stat.gov.rs/WebSite/public/ReportView.aspx

Interdependence between the volume of grape production (in tonnes) and the number of vines, as well as between the volume of grape production and yield per vine is tested in Table 2. 
Table 2. Correlation between the volume of grape production, number of vines and yields per vine

\begin{tabular}{|c|c|c|c|c|}
\hline \multicolumn{5}{|c|}{ Correlations } \\
\hline & & $\begin{array}{c}\text { Number of } \\
\text { vines }\end{array}$ & $\begin{array}{c}\text { Grape } \\
\text { production }\end{array}$ & Yield per vine \\
\hline \multirow{3}{*}{ Number of vines } & Pearson Correlation & 1 & 0.236 & -0.307 \\
\hline & Sig. (1-tailed) & & 0.512 & 0.388 \\
\hline & $\mathrm{N}$ & 10 & 10 & 10 \\
\hline \multirow{3}{*}{ Grape production } & Pearson Correlation & 0.236 & 1 & $0.838(* *)$ \\
\hline & Sig. (1-tailed) & 0.512 & & 0.002 \\
\hline & $\mathrm{N}$ & 10 & 10 & 10 \\
\hline \multirow{3}{*}{ Yield per vine } & Pearson Correlation & -0.307 & $0.838(* *)$ & 1 \\
\hline & Sig. (1-tailed) & 0.388 & 0.002 & \\
\hline & $\mathrm{N}$ & 10 & 10 & 10 \\
\hline
\end{tabular}

** Correlation is significant at the 0.01 level (2-tailed).

Source: Authors' calculation

Based on the values in Table 2, it can be concluded that there is a positive correlation between the volume of grape production and number vines, but also between the volume of grape production and yield per vine. However, correlations between the volume of grape production and yield per vine is stronger and this factor has a greater impact on the volume of production achieved. There is a strong positive correlation between the achieved volume of grape production and yield per vine (correlation coefficient of 0.838 ), while there is a weak positive correlation between the volume of grape production and yield per vine (correlation coefficient of 0.236 ).

The common impact of the number of vines and yield per vine on the achieved volume of grape production in Serbia from 2004 to 2013 is tested in Table 3.

Table 3. The common impact of the number of vines and yield per vine on production volume

\begin{tabular}{|l|c|c|c|r|}
\hline \multicolumn{6}{|c|}{ Model Summary $^{\mathbf{b}}$} \\
\hline Model & $\mathrm{R}$ & R Square & Adjusted R Square & Std. Error of the Estimate \\
\hline 1 & $0.985^{\mathrm{a}}$ & 0.970 & 0.961 & $1.201 \mathrm{E} 7$ \\
\hline a. Predictors: (Constant), Yields, Vines \\
\hline
\end{tabular}

Source: Authors' calculation

The determination coefficient shows which part of the variance of the dependent variable explains the model. The determination coefficient is 0.970 . When we express this ratio in percentage, we can conclude that the common impact of the number of vines and yield per vine on total grape production ammounts $97 \%$.

The individual impact of the number of vines and yield per vine on the achieved volume of grape production in Serbia from 2004 to 2013 is tested in Table 4. 
Table 4. The individual impact of observed factors (number of vines and yield per vine) on the grape production

\begin{tabular}{|c|c|c|c|c|c|c|c|c|c|c|c|}
\hline & \multirow{2}{*}{ Model } & \multicolumn{2}{|c|}{$\begin{array}{l}\text { Unstandardized } \\
\text { Coefficients }\end{array}$} & \multirow{2}{*}{$\begin{array}{c}\begin{array}{c}\text { Standardized } \\
\text { Coefficients }\end{array} \\
\text { Beta }\end{array}$} & \multirow{2}{*}{$t$} & \multirow{2}{*}{ Sig. } & \multicolumn{3}{|c|}{ Correlations } & \multicolumn{2}{|c|}{$\begin{array}{c}\text { Collinearity } \\
\text { Statistics }\end{array}$} \\
\hline & & B & Std. Error & & & & $\begin{array}{l}\text { Zero- } \\
\text { order }\end{array}$ & Partial & Part & Tolerance & VIF \\
\hline \multirow{3}{*}{1} & (Constant) & $-2.850 \mathrm{E} 8$ & $5.129 \mathrm{E} 7$ & & -5.557 & 0.001 & & & & & \\
\hline & Vines & 0.994 & 0.132 & 0.522 & 7.538 & 0.000 & 0.213 & 0.944 & 0.497 & 0.906 & 1.103 \\
\hline & Yield & $2.891 \mathrm{E} 8$ & $1.983 \mathrm{E} 7$ & 1.010 & 14.580 & 0.000 & 0.850 & 0.984 & 0.961 & 0.906 & 1.103 \\
\hline
\end{tabular}

Source: Authors' calculation

Based on the values of Beta coefficients in Table 4, it can be concluded that there is a greater impact of yield per vine in relation to the impact of number of vines on the production volume. When Sig. value is less than 0.05 , variable gives a significant unique contribution to the prediction of the dependent variable. When this value is greater than 0.05 , it must be concluded that this variable does not give a significant unique contribution to the prediction of the dependent variable. Based on the results of the regression method, it can be concluded that both factors have a significant impact on the volume of grape production, with the higher impact of yield per vine, or it can be concluded that the hypothesis $\mathrm{H} 1$ is confirmed.

\section{Serbia on the international wine market}

Regions with vineyard production can be found on the northern and, also, on the southern hemisphere, between 30 and 50 degrees of geographical latitude. The different climatic conditions, soil types and grape varieties were observed among continents, but also within the continents. Table 5 presents data on wine production at the global level, in 15 countries with the largest wine production, wine production in Serbia and wine production in the rest of the world.

Table 5. Wine production in the world, in 15 countries that are the largest wine producers, in Serbia and in the rest of the world from 2004 to 2014 (expressed in thousands of hectoliters)

\begin{tabular}{|l|c|c|c|c|c|c|c|c|c|c|}
\hline \multicolumn{1}{|c|}{ Country } & $\mathbf{2 0 0 4}$ & $\mathbf{2 0 0 5}$ & $\mathbf{2 0 0 6}$ & $\mathbf{2 0 0 7}$ & $\mathbf{2 0 0 8}$ & $\mathbf{2 0 0 9}$ & $\mathbf{2 0 1 0}$ & $\mathbf{2 0 1 1}$ & $\mathbf{2 0 1 2}$ & $\mathbf{2 0 1 3}$ \\
\hline France & 57,386 & 52,105 & 52,127 & 45,672 & 42,654 & 46,269 & 44,381 & 50,757 & 41,548 & 42,004 \\
\hline Italy & 49,935 & 50,566 & 52,036 & 45,981 & 46,970 & 47,314 & 48,525 & 42,772 & 45,616 & 52,429 \\
\hline Spain & 42,988 & 36,158 & 38,273 & 36,408 & 35,913 & 36,093 & 35,353 & 33,397 & 31,123 & 45,650 \\
\hline U. States & 20,109 & 22,888 & 19,440 & 19,870 & 19,340 & 21,965 & 20,890 & 19,140 & 21,740 & 23,500 \\
\hline Argentina & 15,464 & 15,222 & 15,396 & 15,046 & 14,676 & 12,135 & 16,250 & 15,473 & 11,778 & 14,984 \\
\hline Australia & 14,679 & 14,301 & 14,263 & 9,620 & 12,448 & 11,784 & 11,420 & 11,180 & 12,260 & 12,310 \\
\hline China & 11,700 & 11,800 & 11,900 & 12,500 & 12,600 & 12,800 & 13,000 & 13,200 & 13,810 & 11,780 \\
\hline S. Africa & 9,279 & 8,406 & 9,398 & 9,783 & 10,165 & 9,986 & 9,327 & 9,725 & 10,568 & 10,980 \\
\hline Chile & 6,301 & 7,885 & 8,448 & 8,227 & 8,683 & 10,093 & 8,844 & 10,464 & 12,554 & 12,846 \\
\hline Germany & 10,007 & 9,153 & 8,916 & 10,261 & 9,991 & 9,228 & 6,906 & 9,132 & 9,012 & 8,409 \\
\hline Russia & 5,120 & 4,590 & 6,280 & 7,280 & 7,110 & 7,126 & 6,400 & 6,353 & 6,400 & 6,200 \\
\hline Portugal & 7,481 & 7,266 & 7,542 & 6,074 & 5,689 & 5,868 & 7,148 & 5,622 & 6,327 & 6,238 \\
\hline
\end{tabular}




\begin{tabular}{|l|c|c|c|c|c|c|c|c|c|c|}
\hline Romania & 6,166 & 2,602 & 5,014 & 5,289 & 5,159 & 6,703 & 3,287 & 4,058 & 3,311 & 5,113 \\
\hline N. Zealand & 1,192 & 1,020 & 1,332 & 1,476 & 2,052 & 2,050 & 1,900 & 2,350 & 1,940 & 2,484 \\
\hline Greece & 4,248 & 4,027 & 3,938 & 3,511 & 3,869 & 3,366 & 2,950 & 2,750 & 3,115 & 3,343 \\
\hline Serbia & - & - & 1,292 & 1,670 & 1,929 & 2,392 & 2,382 & 2,244 & 2,196 & 2,306 \\
\hline $\begin{array}{l}\text { Rest of } \\
\text { World }\end{array}$ & 33,945 & 29,969 & 27,024 & 28,823 & 29,450 & 26,999 & 25,409 & 28,626 & 22,924 & 27,024 \\
\hline World & 296,000 & 277,958 & 282,619 & 267,491 & 268,698 & 272,171 & 264,372 & 267,243 & 256,222 & 287,600 \\
\hline
\end{tabular}

Source: Italian Wine Centar, available at: http://italianwinecentral.com/top-ten-wine-exporting-countries/; International Organisation of Vine and Wine, available at: http://www.oiv.int/oiv/info/enstatoivextracts2

World wine production was at a level of 287,600 hectolitres in 2013. Production was reduced by $2.84 \%$ from 2004 to 2013 . Regionally, Europe provides the highest part of the world wine production (66.01\%), followed by America (19.20\%) and Asia (5.65\%).

Observed by the countries, the largest fifteen producers of wine makes around about $89.80 \%$ of the total world wine production. In the period from 2004 to 2013 , the share of the fifteen largest wine producers slightly increased from $88.53 \%$ to $89.80 \%$, while the share of France, Italy and Spain decreased from $50.78 \%$ to $48.71 \%$. France $(14.61 \%)$, Italy $(18.23 \%)$ and Spain (15.87\%) have the largest share in the world wine production.

Participation of Serbia in the total world production of wine increased from $0.46 \%$ to $0.80 \%$ from 2006 to 2013. Serbia achieved the largest share in $2010(0.90 \%)$. In the reporting period, Serbia has recorded a growth of wine production at an average annual rate of $8.63 \%$.

Table 6 shows the wine export for the countries that are the largest exporter of wine, in Serbia, in the rest of the world, and the world import/export trade in the observed period.

Table 6. The largest exporters of wine in the world, export in Serbia, in the rest of the world and world import/export trade from 2004 to 2013 (in thousands of hectoliters)

\begin{tabular}{|l|l|l|l|l|l|l|l|l|l|l|}
\hline Country & 2004 & 2005 & 2006 & 2007 & 2008 & 2009 & 2010 & 2011 & 2012 & 2013 \\
\hline Italy & 14,123 & 15,721 & 18,390 & 18,507 & 18,067 & 19,519 & 21,841 & 23,238 & 21,200 & 20,343 \\
\hline Spain & 14,042 & 14,439 & 14,340 & 15,079 & 16,914 & 14,607 & 17,685 & 22,549 & 19,472 & 16,012 \\
\hline France & 14,210 & 13,834 & 14,861 & 14,506 & 12,798 & 12,556 & 13,504 & 14,194 & 14,992 & 14,557 \\
\hline Chile & 4,740 & 4,209 & 4,740 & 6,100 & 5,885 & 6,935 & 7,333 & 6,666 & 7,517 & 8,834 \\
\hline Australia & 6,426 & 7,019 & 7,598 & 7,862 & 6,985 & 7,716 & 7,811 & 7,205 & 7,349 & 7,117 \\
\hline South Africa & 2,677 & 2,811 & 2,717 & 3,126 & 4,117 & 3,956 & 3,786 & 3,752 & 4,128 & 5,544 \\
\hline United States & 3,874 & 3,459 & 3,761 & 4,231 & 4,638 & 3,983 & 3,965 & 4,218 & 4,009 & 4,149 \\
\hline Germany & 2,709 & 2,970 & 3,197 & 3,543 & 3,580 & 3,557 & 3,929 & 4,151 & 3,960 & 4,011 \\
\hline Argentina & 1,553 & 2,148 & 2,934 & 3,598 & 4,141 & 2,831 & 2,744 & 3,171 & 3,647 & 3,156 \\
\hline Portugal & 3,229 & 2,627 & 2,930 & 3,442 & 2,911 & 2,309 & 2,557 & 3,076 & 3,386 & 3,115 \\
\hline Serbia & - & 77 & 84 & 98 & 92 & 112 & 113 & 152 & - & - \\
\hline Rest of world & 9,014 & 9,550 & 9,069 & 8,952 & 9,663 & 9,419 & 10,632 & 6,672 & 9,373 & 11,012 \\
\hline $\begin{array}{l}\text { World im- } \\
\text { port/export } \\
\text { trade }\end{array}$ & 76,597 & 78,864 & 84,621 & 89,044 & 89,791 & 87,500 & 95,900 & 100,726 & 99,033 & 97,850 \\
\hline
\end{tabular}

Source: Italian Wine Centar, available at: http://italianwinecentral.com/top-ten-wine-exportingcountries/; International Organisation of Vine and Wine, available at: http://www.oiv.int/oiv/ info/enstatoivextracts2 
The largest wine producers and the largest exporters of wine in the world are the following countries: Italy (20.79\%), Spain (16.36\%) and France (14.88\%). The share of these countries in the world export of wine is $52.03 \%$. This share dropped from $55.32 \%$ to $52.03 \%$ from 2004 to 2013 . The share of the ten largest exporter of wine in the world wine trade is $88.75 \%$. The share of these countries in the world trade of wine increased slightly from $88.23 \%$ to $88.75 \%$. The market share of Serbia in the world export of wine ranged from $0.097 \%$ to $0.151 \%$ from 2005 to 2011 . Although the Serbian wine export increased in the observed period at an average annual rate of $12 \%$, the share of Serbia in the global wine market is very small.

The share of the ten largest importers of wine in total import is $70.17 \%$. Germany, the United Kingdom and the United States of America are the three largest importers of wine. In the observed period, these countries have increased the volume of imported wine. Germany and the United Kingdom have reduced the share in total import of wines on the world market from $17.68 \%$ to $15.93 \%$ and from $16.19 \%$ to $13.84 \%$, while the United States increased share from $8.6 \%$ to $11.6 \%$. The Republic of Serbia has increased the import of wine for more than 150\% from 2005 to 2011. During this period, share of Serbia in total import of wine increased from $0.16 \%$ to $0.30 \%$. In the same period, coverage of import by export decreased from $63 \%$ to $51 \%$, or import grew faster than export, and import dependence of Serbia, when it comes to wine, increased.

Table 7 shows the import of wine for the countries that are the largest importers, in Serbia, in the rest of the world, as well as at the global level from 2004 to 2013.

Table 7. The largest importers of wine in the world (in thousands of hectoliters)

\begin{tabular}{|l|c|c|c|c|c|c|c|c|c|c|}
\hline \multicolumn{1}{|c|}{ Country } & $\mathbf{2 0 0 4}$ & $\mathbf{2 0 0 5}$ & $\mathbf{2 0 0 6}$ & $\mathbf{2 0 0 7}$ & $\mathbf{2 0 0 8}$ & $\mathbf{2 0 0 9}$ & $\mathbf{2 0 1 0}$ & $\mathbf{2 0 1 1}$ & $\mathbf{2 0 1 2}$ & $\mathbf{2 0 1 3}$ \\
\hline Germany & 13,043 & 13,262 & 14,553 & 14,553 & 13,708 & 14,110 & 14,778 & 16,132 & 15,261 & 15,002 \\
\hline $\begin{array}{l}\text { United } \\
\text { Kingdom }\end{array}$ & 11,945 & 11,727 & 11,287 & 11,677 & 11,515 & 11,859 & 12,861 & 13,295 & 13,124 & 13,032 \\
\hline $\begin{array}{l}\text { United States } \\
\text { ofAmerica }\end{array}$ & 6,415 & 7,052 & 7,718 & 8,373 & 8,250 & 9,219 & 9,320 & 10,155 & 11,666 & 10,966 \\
\hline France & 5,514 & 5,495 & 5,321 & 5,362 & 5,719 & 5,755 & 6,405 & 6,467 & 5,889 & 5,241 \\
\hline $\begin{array}{l}\text { Russian } \\
\text { Federation }\end{array}$ & 5,051 & 6,227 & 6,112 & 6,434 & 5,733 & 4,520 & 5,466 & 5,112 & 4,844 & 4,922 \\
\hline China & 712 & 868 & 1,528 & 1,959 & 2,151 & 2,235 & 3,482 & 4,412 & 3,939 & 3,766 \\
\hline Canada & 2,668 & 2,809 & 3,043 & 3,118 & 3,200 & 3,284 & 3,500 & 3,584 & 3,767 & 3,729 \\
\hline Netherlands & 3,227 & 3,799 & 3,417 & 3,823 & 3,631 & 3,669 & 3,692 & 3,647 & 3,560 & 3,667 \\
\hline Belgium & 2,801 & 2,897 & 2,938 & 3,106 & 3,097 & 3,061 & 2,984 & 3,158 & 3,134 & 3,140 \\
\hline Japan & 1,665 & 1,585 & 1,662 & 1,667 & 1,718 & 1,807 & 1,939 & 2,083 & 2,570 & 2,632 \\
\hline Serbia & - & 122 & 268 & 306 & 245 & 215 & 205 & 298 & - & - \\
\hline $\begin{array}{l}\text { Rest of } \\
\text { world }\end{array}$ & 20,739 & 21,701 & 23,491 & 25,345 & 26,333 & 24,702 & 26,717 & 29,727 & 27,102 & 28,094 \\
\hline $\begin{array}{l}\text { WORLD } \\
\text { TOTAL }\end{array}$ & 73,779 & 77,543 & 80,556 & 85,722 & 85,300 & 84,436 & 91,349 & 98,071 & 94,856 & 94,192 \\
\hline
\end{tabular}

Source: Italian Wine Centar, available at: http://italianwinecentral.com/top-ten-wine-exportingcountries/; International Organisation of Vine and Wine, available at: http://www.oiv.int/oiv/ info/enstatoivextracts2

Regional territorial distribution of production and trade of wine is very different and unequal across the continents and by country. Developed countries in relation to the 
underdeveloped and developing countries achieve greater participation not only in the world production, but also in trade and export and import of wine. In the observed period, the developed countries have maintained share in world production and trade of wine on the international market. Based on the above mentioned, it can be concluded that there is no change in the structure of the international wine market in the observed period. The hypothesis $\mathrm{H} 2$ is confirmed. The largest exporters of wine have maintained its dominant market share on the international wine market. At the same time, the largest importers of wine slightly have increased its import in the analyzed period from 2004 to 2013.

During this period, wine consumption has been increasing at an average annual rate of $0.05 \%$. The ten largest customers absorbed about $68.79 \%$ of the total world consumption of wine. If we look at the total amount of wine consumed (expressed in thousands of hectoliters), the largest consumers are the USA, France and Italy. However, if we look consumption in litres per capita, the largest consumers are Luxembourg (49.81 $\mathrm{l} / \mathrm{per}$ capita), France (46.45 l/per capita), Portugal (43.84 l/per capita) and Italy (37.92 l/ per capita). Recorded consumption in the USA is $9.08 \mathrm{l} /$ per capita. Serbia records the consumption in the amount of $13.11 \mathrm{l} /$ per capita, while its share in the total world consumption of wine is around $0.53 \%$.

Table 8 shows the consumption of wine in the countries that are the biggest consumers of wine, as well as a comparative overview of the consumption of wine in Serbia, in the rest of the world and at the global level.

Table 8. The largest consumers of wine in the world (in thousands of hectoliters)

\begin{tabular}{|l|c|c|c|c|c|c|c|c|c|c|}
\hline Country & $\mathbf{2 0 0 4}$ & $\mathbf{2 0 0 5}$ & $\mathbf{2 0 0 6}$ & $\mathbf{2 0 0 7}$ & $\mathbf{2 0 0 8}$ & $\mathbf{2 0 0 9}$ & $\mathbf{2 0 1 0}$ & $\mathbf{2 0 1 1}$ & $\mathbf{2 0 1 2}$ & $\mathbf{2 0 1 3}$ \\
\hline U. States & 24,750 & 25,850 & 26,700 & 27,850 & 27,700 & 27,250 & 27,600 & 28,425 & 29,000 & 29,145 \\
\hline France & 33,218 & 33,530 & 33,003 & 32,169 & 30,800 & 30,215 & 29,272 & 29,322 & 30,269 & 28,181 \\
\hline Italy & 28,300 & 27,016 & 27,332 & 26,700 & 26,166 & 24,100 & 24,624 & 23,052 & 22,633 & 21,795 \\
\hline Germany & 19,845 & 19,848 & 20,210 & 20,782 & 20,747 & 20,224 & 20,200 & 19,707 & 20,000 & 20,300 \\
\hline China & 12,367 & 12,611 & 13,339 & 14,292 & 14,460 & 14,514 & 15,180 & 16,339 & 17,477 & 16,815 \\
\hline UK & 12,742 & 13,143 & 12,672 & 13,702 & 13,483 & 12,680 & 12,900 & 12,860 & 12,801 & 12,738 \\
\hline Russia & 9,159 & 9,809 & 11,251 & 12,690 & 11,840 & 10,368 & 12,197 & 11,276 & 10,394 & 10,500 \\
\hline Argentina & 11,113 & 10,972 & 11,103 & 11,166 & 10,677 & 10,342 & 9,753 & 9,809 & 10,051 & 10,337 \\
\hline Spain & 13,898 & 13,686 & 13,514 & 13,100 & 12,168 & 11,271 & 10,896 & 9,894 & 9,300 & 9,100 \\
\hline Australia & 4,361 & 4,523 & 4,567 & 4,903 & 4,932 & 5,120 & 5,351 & 5,325 & 5,396 & 5,289 \\
\hline Serbia & - & - & 1,476 & 1,878 & 2,082 & 2,495 & 1,292 & 1,292 & - & - \\
\hline $\begin{array}{l}\text { Rest of } \\
\text { world }\end{array}$ & 67,881 & 65,894 & 71,776 & 75,939 & 76,197 & 74,721 & $72,, 535$ & 76,499 & 75,679 & 74,500 \\
\hline World & 237,634 & 236,882 & 246,943 & 255,171 & 251,252 & 243,300 & 241,800 & 243,800 & 243,000 & 238,700 \\
\hline
\end{tabular}

Source: Italian Wine Centar, available at: http://italianwinecentral.com/top-ten-wine-exportingcountries/; International Organisation of Vine and Wine, available at: http://www.oiv.int/oiv/ info/enstatoivextracts2

Serbia reduced consumption of wines from 1,476,000 to $1,292,000$ hectolitres in the analysed period. Participation of Serbia in the global wine consumption declined from 0.59 to $0.53 \% \%$ in this period. The largest share was recorded in 
$2009(1.025 \%)$, when the highest per capita consumption of wine in Serbia was recorded also (25.33 l/per capita).

Significantly higher consumption of wine in relation to the wine production was recorded in Serbia from 2006 to 2009. During this period, the production covered about $90 \%$ of wine consumption in Serbia. However, wine production in Serbia was higher by about $80 \%$ in relation to wine consumption in 2010 and 2011 . In the period from 2006 to 2011, the share of export in total wine production ranged from 4.7\% (2009 and 2010) to $6.7 \%$ (2011). In the same period, import of wine was two or three times higher than the export of wines from Serbia.

\section{Wine import and export of the Republic of Serbia}

Based on the data from Figure 1, it can be concluded that the import was increasing at an average annual rate of $12.94 \%$, while wine export was increasing at an average annual rate of $8.41 \%$ in the same period. In the observed period, the wine foreign trade deficit of Serbia with the other world countries was increasing at an average rate of $21.47 \%$. This confirms the hypothesis H3.

Figure 1. Movement of the Serbian import and export of wines (in thousands of dollars)

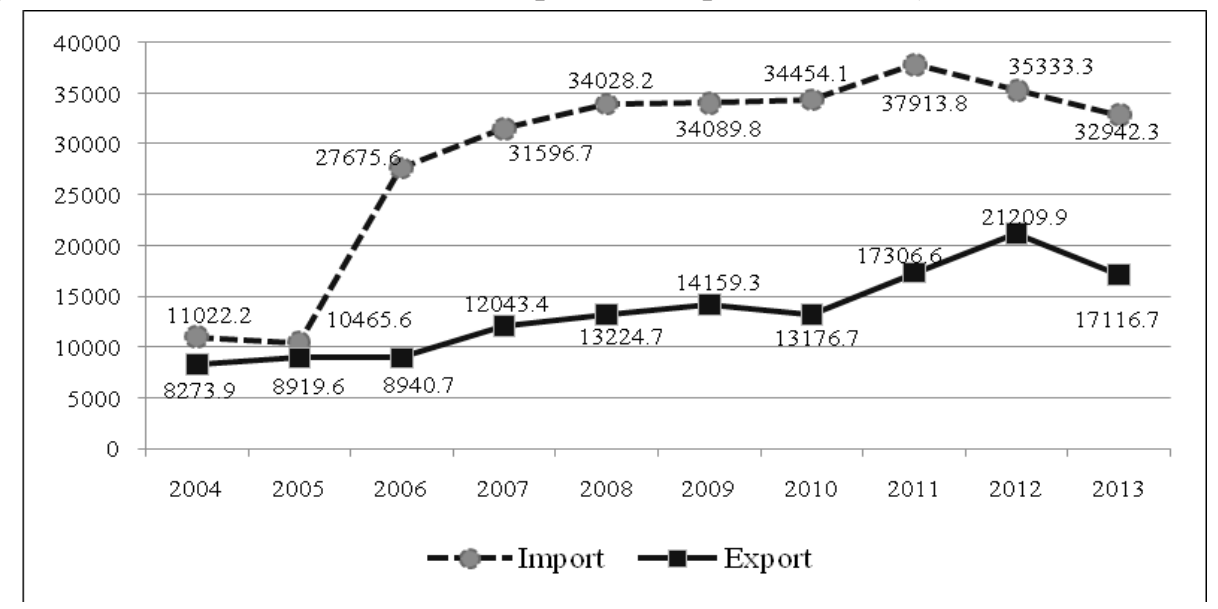

Source: Statistical Office of the Republic of Serbia, aviable at: http://webrzs.stat.gov.rs/ WebSite/public/ReportView.aspx

In order to accurately determine the position of Serbia regarding import and export of wine, we calculate the coefficient of coverage of wine import by wine export in the period from 2004 to 2013 . For the state is acceptable the situation when the value of this ratio is greater than one. In our case, the coefficient is less than one. The ratio ranged from 0.751 (2004) to 0.520 (2013) in the observed period, or the coverage of import by export decreased. Based on the above mentioned, it can be concluded that the hypothesis $\mathrm{H} 4$ is confirmed. 
Figure 2 shows the structure of the wine export from Serbia by importing countries. The largest wine export from Serbia in 2004 was recorded in the following countries: Bosnia and Herzegovina (5183.4 thousand dollars, or which represented $62.65 \%$ of the total export of Serbia), Austria (949.9 thousand dollars, or 11.76\%) and Germany (927.7 thousand dollars, or 11.48\%). Export from Serbia to Bosnia and Herzegovina (5124 thousands of dollars, or 29.94\% of the total export of Serbia), Austria (127.8 thousand dollars, or $0.75 \%$ ) and Germany (66.9 thousand dollars, or $0.39 \%$ ) reduced in 2013. However, export to the Russian Federation (14.1 to 5704.2 thousand dollars, or from $0.17 \%$ to $33.33 \%$ ) and to the Czech Republic (from 71.9 to 785.5 thousand dollars, or with $0.87 \%$ at $4.59 \%$ ) increased. Important export to Montenegro in the amount of 3051.2 thousand dollars was recorded in 2013.

Figure 2. Structure of wine export from Serbia by countries in 2004 and 2013 (in \%)

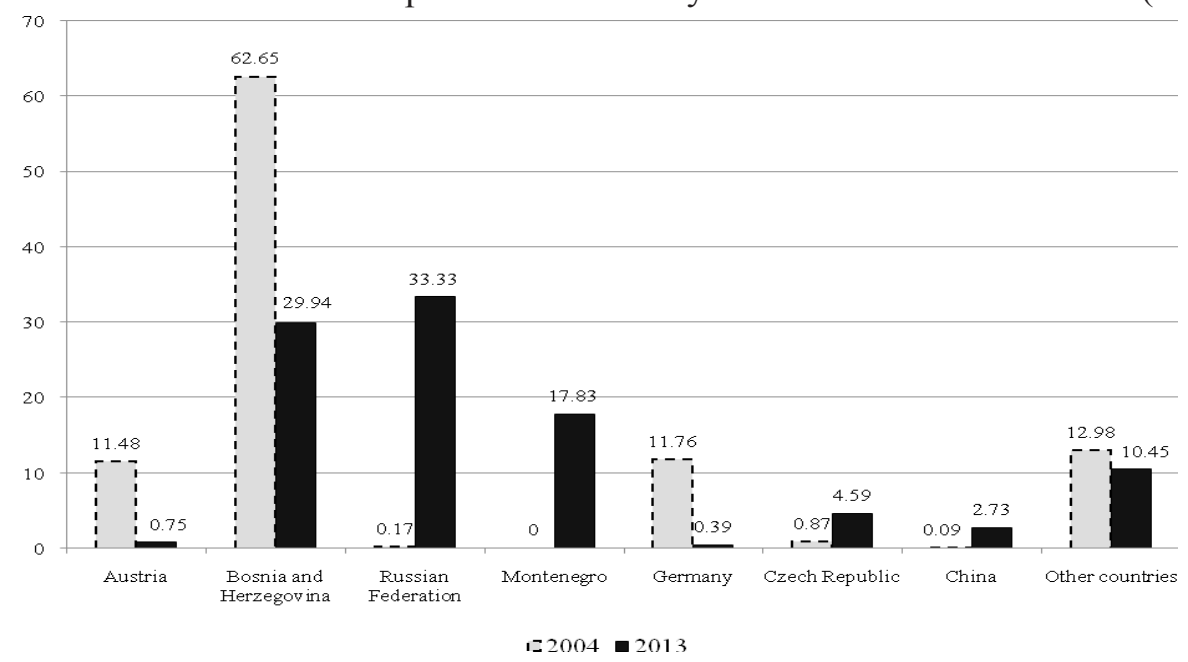

Source: Authors' calculation based on data of the Statistical Office of the Republic of Serbia, available at: http://webrzs.stat.gov.rs/WebSite/public/ReportView.aspx.

When it comes to the structure of wine import by countries (Figure 3), Serbia has the highest wine import from the Republic of Macedonia. 
Figure 3. Structure of wine import of Serbia by countries in 2004 and 2013 (in \%)

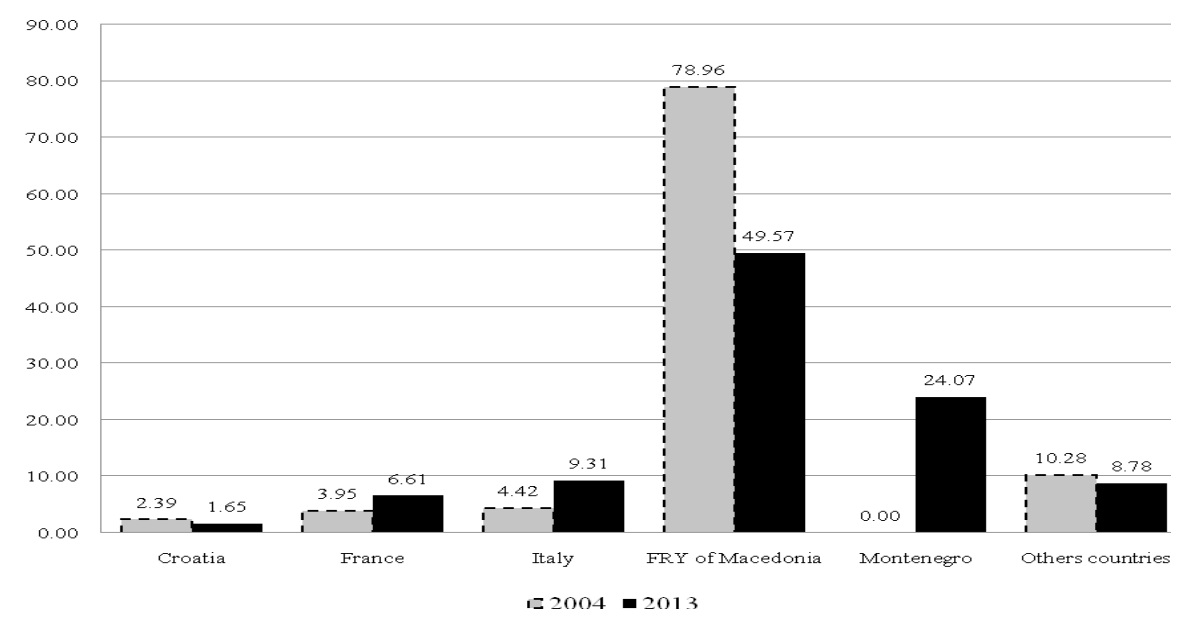

Source: Authors' calculation based on data of the Statistical Office of the Republic of Serbia, available at: http://webrzs.stat.gov.rs/WebSite/public/ReportView.aspx.

Serbia realized the import of wine from Macedonia in the amount of 8,702.6 thousand dollars in 2004, and in the amount of 16,329.7 thousand dollars in 2013. The share of import of wine from Macedonia to Serbia in total import was reduced in 2013 (49.57\%) compared to the total import recorded in 2004 (78.96\%).

\section{Conclusion}

Given that Serbia has favourable conditions for growing vines, viticulture is a traditional branch of agriculture. Tendency of reducing the number of vines was observed in the nineties of the last century. Although the formation of large surfaces with an innovative, modern and adapted to our circumstances growing forms of vines marked the first decade of the XXI century, the tendency to reduce the number of vines in Serbia is continued. This impacted on the reduction of grape production in this period. Using the regression and correlation analysis, we determined that, in the observed period, the yield per vine has a greater impact on the volume of production of grapes, in relation to the impact of number of vines.

The tendency of reducing the area under vines was also recorded in the most important wine producers in the world (France, Spain and Italy), as a result of the qualitative changes that were apparent in the last few years in viticulture, which relate to the reduction of the area under the existing plantations and the formation the plantations which are the basis for the production of high quality wines. Reduction in vineyard area did not significantly reduce wine production in these countries, and they have retained an important place as producers on the international wine market. Based on trends in production, export and import of wine on the international market, we conclude that there has been no significant change in the structure of the international wine market 
in the observed period. Countries that were leaders at the beginning of the period, have maintained its leadership position at the end of the period.

In addition to the very favourable conditions for grape growing, wine production in Serbia is at a significantly lower level than in countries with similar natural conditions. Serbia has very favourable, but not sufficiently used, both natural and other resources for achieving the much larger, more stable, higher quality, more structurally adequate and to market better adapted production of wine. Negative tendencies in production and export are the resultant of direct and indirect impacts of numerous causes and circumstances, those in the nineties of the twentieth century, as well as those from the most recent period. As a particularly important causes in the XXI century, we can mention: reducing the number of vines, inefficient transition process, insufficient investment in the development of viticulture and wine production, the lack of adequate integrated development program for the production and processing of agricultural products, inadequate organization and insufficient material and technical equipment of family farms engaged in the grape and wine production, a low level of labor productivity of farms and wineries, inadequate organization of marketing surpluses of grapes and ineffective implementation of international standards.

The above mentioned causes of unfavourable development in the domestic production of wine strongly influenced the current situation in the foreign trade of wines from Serbia with the other countries in the world. Based on the analysis of foreign trade of wines from Serbia with other countries, we have proved that the foreign trade deficit of wines increased, while the ratio of coverage of import by export decreased in the observed period. According to previous, the elimination of the causes of the current negative trends of the observed phenomenon is a priority task in achieving faster development not only the domestic production of grapes and wine, but also in reducing the deficit of foreign trade of wine, or achieving a surplus over a longer period of time and reducing import dependence of Serbia.

The intention of the authors was to obtain research results that can have practical significance. In this sense, the analysis of the tendencies and patterns in the production of grapes, as the basic resources of wine production, can serve to the business decision makers at the micro level, such as enterprises and family farms. Analysis of trends and position of Serbia on the international wine market is valid for making decisions by the creators of agro-economic policies in order to stimulate production and improve the competitive position of the country on the international market.

\section{References}

1. Anderson, K., Norman, D., Wittwer, G. (2001): Globalization and the World's Wine Markets: Overview, Discussion Paper No. 0143, Centre for International Economic Studies, Adelaide University, Australia.

2. Arfini, F., Albisu, L. M., Giacomini, C. (2011): Current situation and potential development of geographical indications in Europe, in Barham, E., Sylvander, B. (Eds), Labels of origin for food: local development, global recognition, CABI, Cambridge, 
United Kingdom, pp. 29-44.

3. Cox, J., Bridwell, L. (2007): Australian companies using globalisation to disrupt the ancient wine industry, International Business Journal, Emerald, United Kingdom, vol. 17, no. 4, pp. 209-221.

4. Đorović, M., Stevanović, S., Lazić, V. (2012): Srbija na međunarodnom tržištu vina, Marketing, Srpsko udruženje za marketing, Beograd, Srbija, vol. 43, no. 1, pp. 15-23.

5. Fleming, E, Mounter, S., Grant, B., Griffith, G., Villano, R. (2014): The New World challenge: Performance trends in wine production in major wine-exporting countries in the 2000s and their implications for the Australian wine industry, Wine Economics and Policy, Elsevier B.V., vol. 3, no. 2, pp. 115-126, (available at: www.sciencedirect. $\underline{\text { com) }}$.

6. Fronkova, M. (2011): Competitiveness of Czech wine producers during financial and economic crisis, Proceedings from the conference - Trends in international business, Prague, Czech, pp. 169-177.

7. Harward, Upto. (1961): Introduction to Business Finance, Mc Graw Hill, New York, USA.

8. International Organisation of Vine and Wine, (available at: http://www.oiv.int/oiv/ info/enstatoivextracts2).

9. Italian Wine Centar, (available at: http://italianwinecentral.com/top-ten-wineexporting-countries/).

10.Krstić, B., Petrović, B. (2012): Uloga upravljanja znanjem u povećanju inovativnosti preduzeća, Facta Universitatis - series: Economics and Organization, Univerzitet $\mathrm{u}$ Nišu, Niš, Srbija, vol. 9, no. 1, pp. 93-110.

11. Kucerova, R. (2014): Factors of the attractiveness of Slovak wine market and their influence on the Czech wine export to Slovakia, Agricultural Economics - Czech, Czech Academy of Agricultural Sciences, Prague, Czech, vol. 60, no. 9, pp. 430-439.

12. Prdić, N., Kuzman, B., Barjaktarović, M. (2014): Practical research results of a successfull company's appearance at the fair, Economics of Agriculture, Institute of Agricultural Economics, Belgrad, Serbia, vol. 61, no. 4, pp. 37-49.

13. Statistical Office of the Republic of Serbia. (1998): Poljoprivreda Srbije 1947-1996, Beograd, Srbija, (available at: http://webrzs.stat.gov.rs/WebSite/public/ReportView. aspx).

14. Statistical Office of the Republic of Serbia. Biljna proizvodnja, (available at: http:// webrzs.stat.gov.rs/WebSite/public/ReportView.aspx).

15. Statistical Office of the Republic of Serbia. Gazdinstva pod različitim usevima prema veličini korišćenog poljoprivrednog zemljišta, (available at: http://webrzs.stat. gov.rs/WebSite/public/ReportView.aspx).

16. Tregear, A., Arfini, F., Belletti, G., Marescotti, A. (2007): Regional foods and rural development: The role of product qualification, Journal of Rural Studies, Elsevier, vol. 23, no. 1, pp. 12-22.

EP 2015 (62) 3 (813-829) 
17. Vita, G., Amico, M. (2013): Origin designation and profitability for small wine grape growers: evidence from a comparative study, Ekonomika poljoprivrede, Institut za ekonomiku poljoprivrede, Beograd, Srbija, vol. 60, no. 1, pp. 7-24.

18.Vlahović, B., Potrebić, V., Jeločnik, M. (2012): Preferences of wine consumers on Serbian market, Ekonomika poljoprivrede, Institut za ekonomiku poljoprivrede, Beograd, Srbija, vol. 59, no. 1, pp. 37-49.

19. Vlahović, B., Tomić, D., Puškarić, A. (2008): Proizvodnja vina u Republici Srbiji, Ekonomika poljoprivrede, Institut za ekonomiku poljoprivrede, Beograd, Srbija, vol. 55, no. 3, pp. 277-288.

20.Vlahović, B., Tomić, D., Puškarić, A. (2011): Change at wine market in the countries of CEFTA region, Economics of Agriculture, Institute of Agricultural Economics, Belgrad, Serbia, vol. 58, no. 4, pp. 609-620.

21. Wittwer, G., Rothfield, J. (2005): Projecting the world wine market from 2003 to 2010, Australasian Agribusiness Review, vol. 13, paper 21, The University of Melbourne, Melbourne, Australia, (available at: http://www.agrifood.info/review/2005/ Wittwer_Rothfield.html). 


\title{
ANALIZA PROIZVODNIH POTENCIJALA I KONKURENTSKE POZICIJE SRBIJE NA MEĐUNARODNOM TRŽIŠTU VINA ${ }^{5}$
}

\author{
Jelena Petrovićé, Bojan Krstić7, Tanja Stanišić ${ }^{8}$
}

\begin{abstract}
Rezime
Svrha istraživanja je analiziranje $i$ prognoziranje najvažnijih trendova na međunarodnom tržištu vina, kao i sagledavanje mogućnosti za povećanje izvoza vina iz Srbije. Cilj istraživanja je da se primenom odgovarajuće metodologije analizira kretanje proizvodnje i prometa vina na međunarodnom tržištu. Rad je strukturiran iz sledećih segmenata: 1) ispitivanje uticaja broja čokota i prinosa po čokotu na ostvareni obim proizvodnje grožđa u posmatranom periodu u Republici Srbiji;2) ispitivanje konkurentskog položaja Republike Srbije na međunarodnom tržištu vina; i 3) analiza vrednosti i strukture spoljnotrgovinske razmene vina Srbije sa drugim državama. U radu su korišćene komparativna, korelaciona i regresiona analiza. Rezultati u radu su ukazali: 1) na veći uticaj prinosa po čokotu na obim proizvodnje grozđa u odnosu na uticaj broj čokota na obim proizvodnje grozdja; 2) da se povećava deficit spoljnotrgovinske razmene vina Srbije sa drugim državama sveta; i 3) da je u posmatranom periodu Srbija smanjila pokrivenost uvoza izvozom vina.
\end{abstract}

Ključne reči: vino, proizvodnja, tržište, spoljnotrgovinska razmena.

5 Rad je deo istraživanja u okviru projekta broj 179066 - Unapređenje konkurentnosti javnog i privatnog sektora umrežavanjem kompetencija u procesu evropskih integracija Srbije, finansiranog od strane Ministarstva prosvete, nauke i tehnološkog razvoja Republike Srbije.

6 Doc. dr Jelena Petrović, Univerzitet u Nišu, Prirodno - matematički fakultet, Višegradska 33, 18000 Niš, Srbija, Telefon: +381631132768, E-mail: jelenapetrovic619@yahoo.com

7 Prof. dr Bojan Krstić, Univerzitet u Nišu, Ekonomski fakultet, Trg Kralja Aleksandra 11, 18000 Niš, Srbija, E-mail: bojan.krstic@eknfak.ni.ac.rs

8 Doc. dr Tanja Stanišić, Univerzitet u Kragujevcu, Fakultet za hotelijerstvo i turizam u Vrnjačkoj Banji, Vojvođanska bb, 36210 Vrnjačka Banja, E-mail: tanja.stanisic@gmail.com

EP 2015 (62) 3 (813-829) 